\title{
Boxwood Blight Disease: A Diagnostic Guide
}

\author{
Vanina L. Castroagudín, ${ }^{1,2}$ Xiao Yang, ${ }^{2,3}$ Margery L. Daughtrey, ${ }^{4}$ Douglas G. Luster, ${ }^{3}$ Jay W. Pscheidt, ${ }^{5}$ Jerry E. Weiland, ${ }^{6}$ and \\ Jo Anne Crouch ${ }^{1, t}$ \\ ${ }^{1}$ United States Department of Agriculture-Agricultural Research Service (USDA-ARS), Mycology and Nematology Genetic Diversity and \\ Biology Laboratory, Beltsville, MD 20705 \\ ${ }^{2}$ Oak Ridge Institute for Science and Education, ARS Research Participation Program, Oak Ridge, TN 37830 \\ ${ }^{3}$ USDA-ARS, Foreign Disease-Weed Science Research Unit, Frederick, MD 21702 \\ ${ }^{4}$ School of Integrative Plant Science, College of Agriculture and Life Sciences, Cornell University, Ithaca, NY 14853 \\ ${ }^{5}$ Department of Botany and Plant Pathology, Oregon State University, Corvallis, OR 97331 \\ ${ }^{6}$ USDA-ARS, Horticultural Crops Research Laboratory, Corvallis, OR 97330
}

Accepted for publication 20 July 2020.

Keywords: Buxaceae, Calonectria, Cylindrocladium, woody ornamentals

Pathogen: Boxwood blight is caused by two closely related fungi: Calonectria henricotiae Gehesquière, Heungens and J.A. Crouch (Gehesquière et al. 2016) (Che) and Calonectria pseudonaviculata (Crous, J.Z. Groenew. \& C.F. Hill) L. Lombard, M.J. Wingf. \& Crous (Lombard et al. 2010a) (Cps). In the past, Cps was known as Cylindrocladium pseudonaviculatum Crous, J.Z. Groenew. \& C.F. Hill and Cylindrocladium buxicola Henricot (Crous et al. 2002; Henricot and Culham 2002; LeBlanc et al. 2018).

\section{Taxonomy}

Classification. Kingdom Fungi, subkingdom Dikarya, phylum Ascomycota, subphylum Pezizomycotina, class Sordariomycetes, subclass Hypocreomycetidae, order Hypocreales, family Nectriaceae, genus Calonectria (Gehesquière et al. 2016; Lombard et al. 2010a).

Electronic resources. The current taxonomic status of Che and Cps can be retrieved from the United States National Fungus Collections Fungal Database at https://nt.ars-grin.gov/fungaldatabases/ (Farr and Rossman 2020).

\section{${ }^{\dagger}$ Corresponding author: J. A. Crouch; joanne.crouch@usda.gov}

Funding: Funding was provided by the USDA-Agricultural Research Service projects 8042-22000-298-00-D and 2072-22000-043-00-D, USDA-Agricultural Research Service Floriculture Nursery Research Initiative project 0500-00059001-00-D, and USDA-National Institute of Food and Agriculture Hatch Fund 1017185. The ARS Research Participation Program of the Oak Ridge Institute for Science and Education (ORISE) administered the appointments of V. Castroagudín and X. Yang through an interagency agreement between the U.S. Department of Energy (DOE) and the USDA. ORISE is managed by Oak Ridge Associated Universities under DOE contract number DE579AC05-06OR23100.

Mention of trade names or commercial products in this publication is solely for the purpose of providing specific information and does not imply recommendation or endorsement by the USDA. USDA is an equal opportunity provider and employer.

*The $\boldsymbol{e}$-Xtra logo stands for "electronic extra" and indicates that one supplementary table is published online.

The author(s) declare no conflict of interest.

This article is in the public domain and not copyrightable. It may be freely reprinted with customary crediting of the source. The American Phytopathological Society, 2020

\section{Symptoms and Signs}

Symptoms of boxwood blight on boxwood (Buxus spp.) include leaf spots or blotches, rapid defoliation, and stem lesions (Figs. 1, 2, 3 , and 4). Leaf symptoms are most abundant during the growing season, whereas stem lesions are visible year-round (Henricot et al. 2000). Symptoms often start low in the canopy or from the interior of the plant (Fig. 1E), where leaves and stems remain moist for longer periods of time. Infection centers are at first randomly scattered or associated with newly introduced plants in the landscape (Figs. 1A and $\mathrm{D}$, and 2D). After repeated disease cycles, entire hedges or field plots may become diseased (Figs. 1B, C, E, and F, and 2A to C).

Leaf symptoms begin as small, brown to black specks that enlarge into discrete spots or diffuse blotches up to $1 \mathrm{~cm}$ in diameter. The centers of the spots eventually become tan with an outer ring of black, necrotic tissue. A yellow, orange, or red halo sometimes develops around the spots as the surrounding leaf tissue begins to die (Fig. 3A and B). Infected leaves abscise, resulting in an accumulation of leaf litter underneath the plant. Entire leaves may blight rapidly, turning tan, gray, or black, shriveling, and falling off within a week (Fig. 3D to F). Symptoms develop more rapidly on highly susceptible cultivars, on younger plant tissues, or when environmental conditions are optimal for rapid infection (warm and moist). Leaf symptoms may be confused with those caused by chemical burns or winter damage, which may have a similar appearance but typically do not lead to defoliation (Daughtrey 2019).

Stem lesions are dark brown to black, small (1 to $3 \mathrm{~mm}$ wide by 1 to $20 \mathrm{~mm}$ long), and may have a lighter tan center. These are especially apparent on younger stems $<2$ years old that have not developed a secondary periderm (Fig. 3C). After defoliation has occurred, stems appear bare, and the canopy may look sparse (Figs. 2F and 3D). New growth may develop on mildly affected stems and mask symptoms occurring lower in the canopy. In severe cases, multiple stems or the entire plant may blight rapidly and die. Similar stem lesions may also be caused by Colletotrichum theobromicola, Pseudonectria spp., or chemical burns (Singh and Doyle 2017). Extensive leaf browning on Buxus can also indicate an infestation of boxwood leafminer (Monarthropalpus flavus). Leafminer feeding may cause spotting on the upper leaf surface and blisters on the abaxial side; slicing into these blisters will reveal the yellow larvae or orange pupae (Daughtrey et al. 2016). 
Under humid conditions, both leaf spots and stem lesions due to boxwood blight develop distinct signs of the pathogen: white sporodochia with tufts of conidiophores (Fig. 4A to C) bearing long, narrow, hyaline asexual spores (see the Pathogen Identification section below). These tufts of conidiophores are visible with the naked eye or hand lens, and they appear almost crystalline under the dissecting microscope at $200 \times$ (Fig. 4C). Thick-walled, brown to black microsclerotia are formed in infected tissues; these are an important part of the long-term survival of the fungus but are not visible to the naked eye (Fig. 4D to G) (Shishkoff and Camp 2016).

In the Pacific Northwest of the United States, boxwood plants grown in urban landscapes or nursery production fields often do not present severe symptoms due to drier summer weather conditions (Fig. 5A) (Weiland and Pscheidt 2020). Disease severity can be very mild (one to three small leaf spots or stem lesions per plant) and can be hidden by new, healthy canopy (Sacher et al. 2020; Weiland and Pscheidt 2020). However, even with mild symptoms, disease incidence in nursery fields may be high, affecting from 50 to $100 \%$ of the plants. Under these circumstances, plants may appear healthy from a distance, but upon closer inspection, widespread infection may be observed (J. E. Weiland, personal communication; Fig. 5B).

\section{Host Range}

Che and $C p s$ are known to infect economically and ecologically important boxwood, such as Buxus sempervirens, B. microphylla,
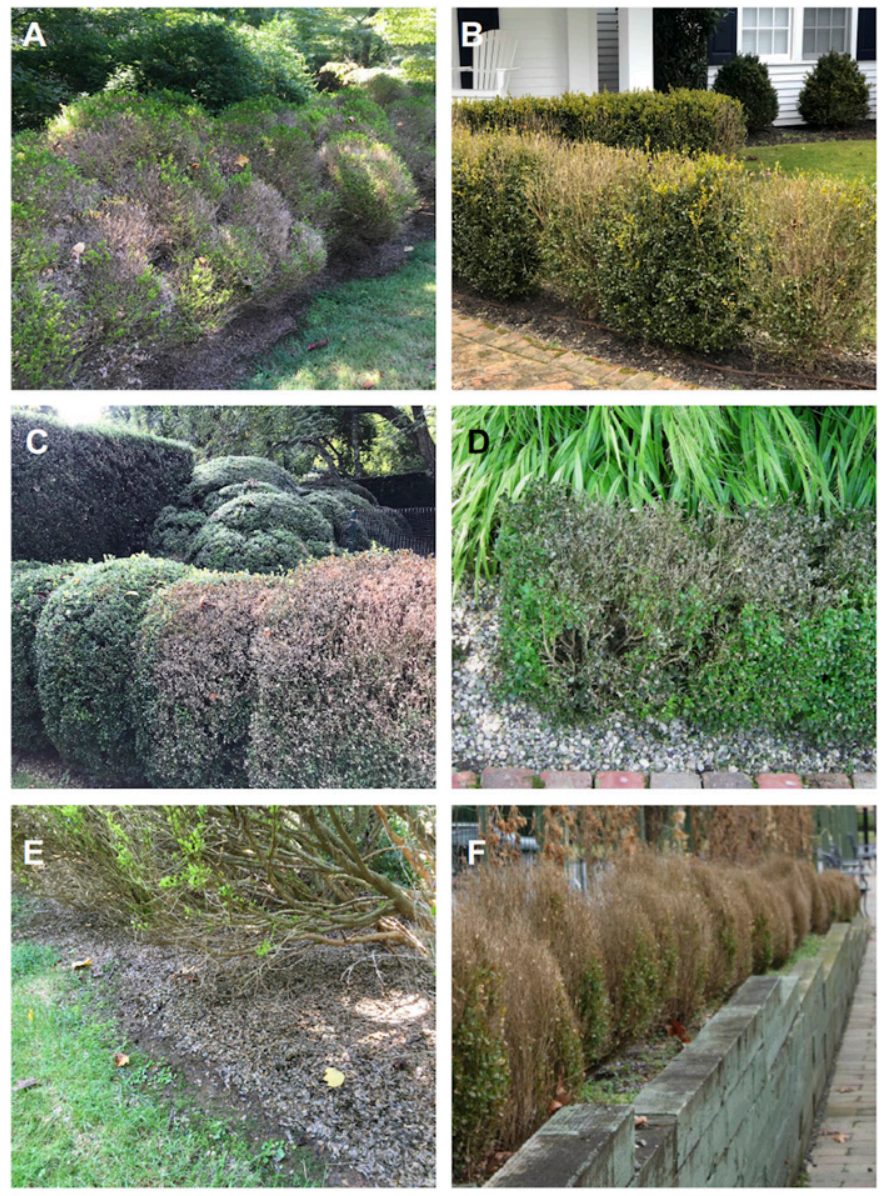

FIGURE 1

A to F, Boxwood (Buxus spp.) affected by boxwood blight disease in residential and public landscapes, showing damaged canopy, dieback, and defoliation. Panel F courtesy of the Connecticut Agricultural Experimental Station. and B. sinica (Shishkoff et al. 2015). Buxus spp. and cultivars reported as hosts of Che and Cps are listed in Supplementary Table S1. Most of these hosts have been identified through artificial inoculation experiments, not through detections of natural infections in nurseries, arboreta, or landscapes. Unfortunately, information on cultivar identity is not generally available for disease sightings from established landscapes. Natural infections have been found in all situations, from nursery to landscape gardens to natural ecosystems (Daughtrey 2019). Although the pathogenicity of Che and Cps on other Buxus spp. still requires evaluation, it is likely that the host range may encompass most Buxus spp., because no boxwood species or cultivars tested so far are immune to these pathogens (Kramer et al. 2020; LaMondia and Shishkoff 2017).

Cps also infects Sarcococca (Fig. 6A to C) and Pachysandra spp. (Fig. 6D and E), which are genera in the Buxaceae family. Henricot et al. (2008) reported an unspecified species of Sarcococca (sweetbox) as a host of Cps through artificial inoculations. Naturally $C p s$-infected $S$. hookeriana var. humilis plants were observed in Maryland (Malapi-Wight et al. 2016b) and Virginia (Kong et al. 2017a) in the United States. Thereafter, at least 27 Sarcococca spp.
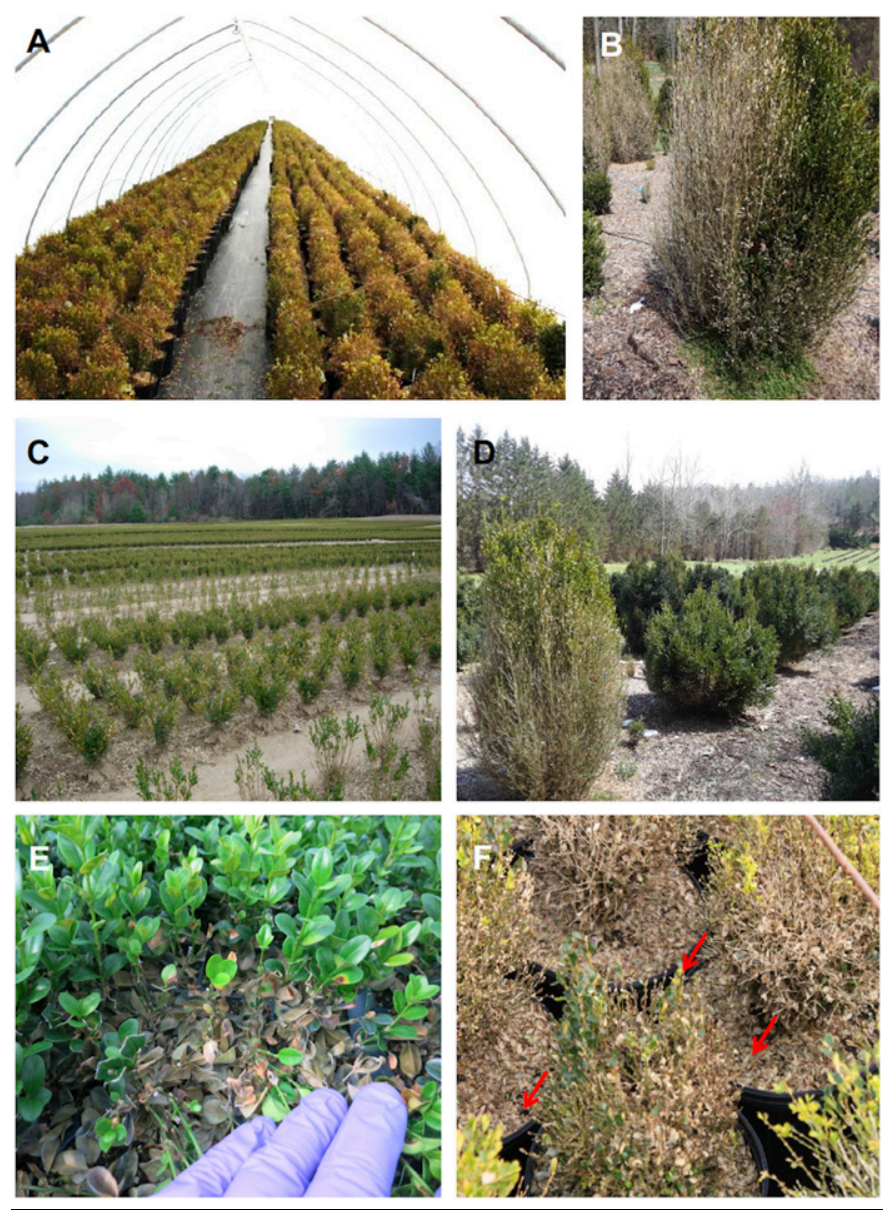

\section{FIGURE 2}

Boxwood blight affecting plants in nursery production. A, Hoop house with boxwood (Buxus spp.) at various stages of decline. B to $\mathbf{D}$, Production plots with extensive boxwood blight in field-grown plants; the 7.5-acre field in panel C suffered a $100 \%$ loss. E, Foliar symptoms in a propagation tray. F, Excessive defoliation and leaf debris in container-grown boxwood plants as indicated by arrows. Panels A and F courtesy of the Connecticut Agricultural Experimental Station (CAES); panel C courtesy of Victoria L. Smith (CAES). 

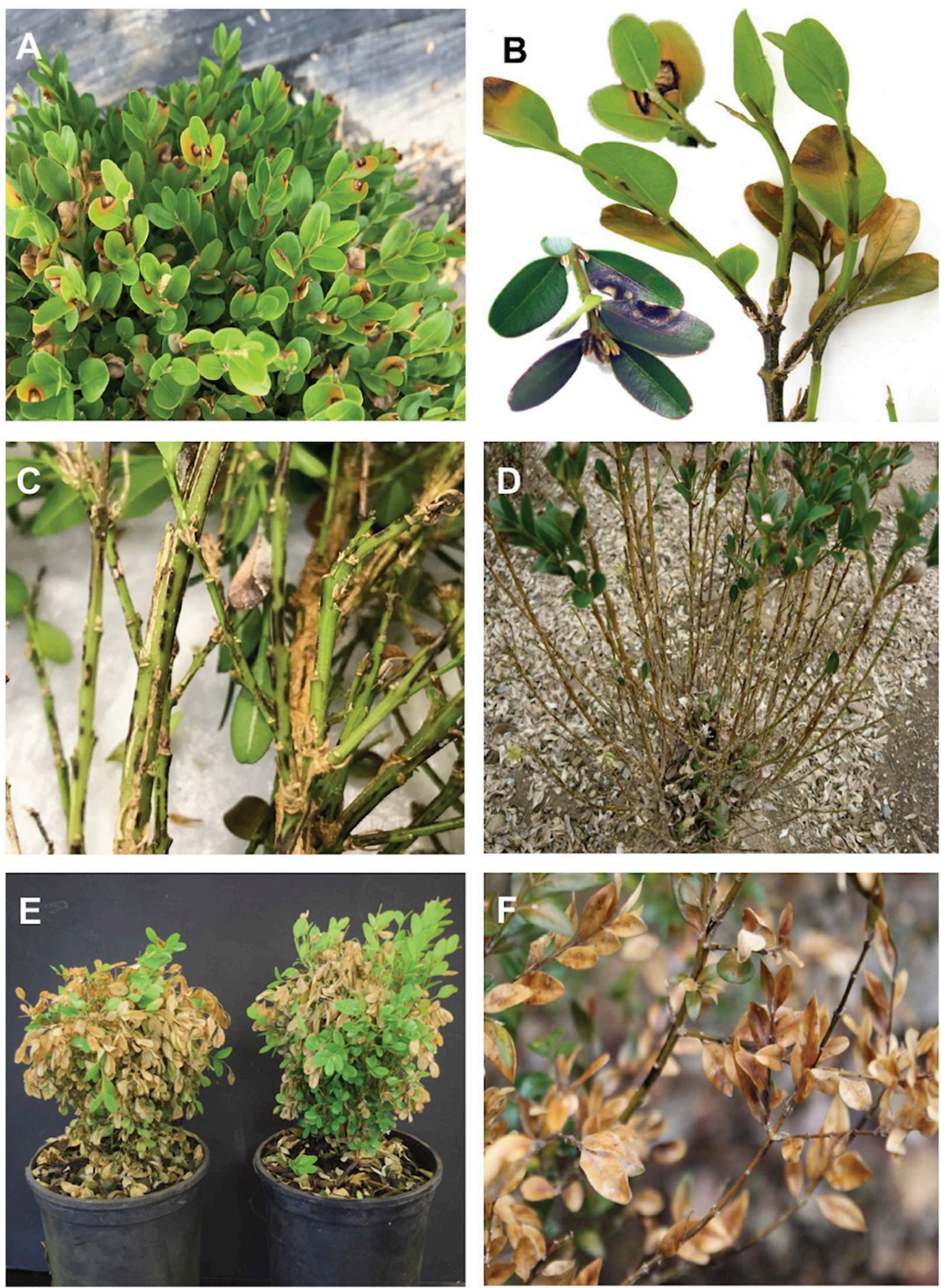

FIGURE 3

Symptoms of boxwood blight on boxwood (Buxus spp.). A and B, Close-up of circular spots and zonate lesions on leaves. C, Distinctive black streaks on stems (also called stem cankers). D, Dieback and extreme defoliation on stems. E and F, Blighted appearance on boxwood foliage. Panel D courtesy of Victoria L. Smith (Connecticut Agricultural Experimental Station; CAES); panel F courtesy of CAES. 
were recognized as hosts of Cps when artificially inoculated (Ryan et al. 2018). It is unknown whether Che can infect Sarcococca spp.

Natural infections on Pachysandra terminalis were observed at landscape sites in Connecticut and Virginia in the United States
(Douglas 2012; Kong et al. 2017b). Under laboratory and greenhouse conditions, $C p s$ is shown to cause leaf and stem lesions on at least six cultivars of $P$. terminalis (LaMondia 2017; LaMondia et al. 2012), P. procumbens (LaMondia and Li 2013), and P. axillaris
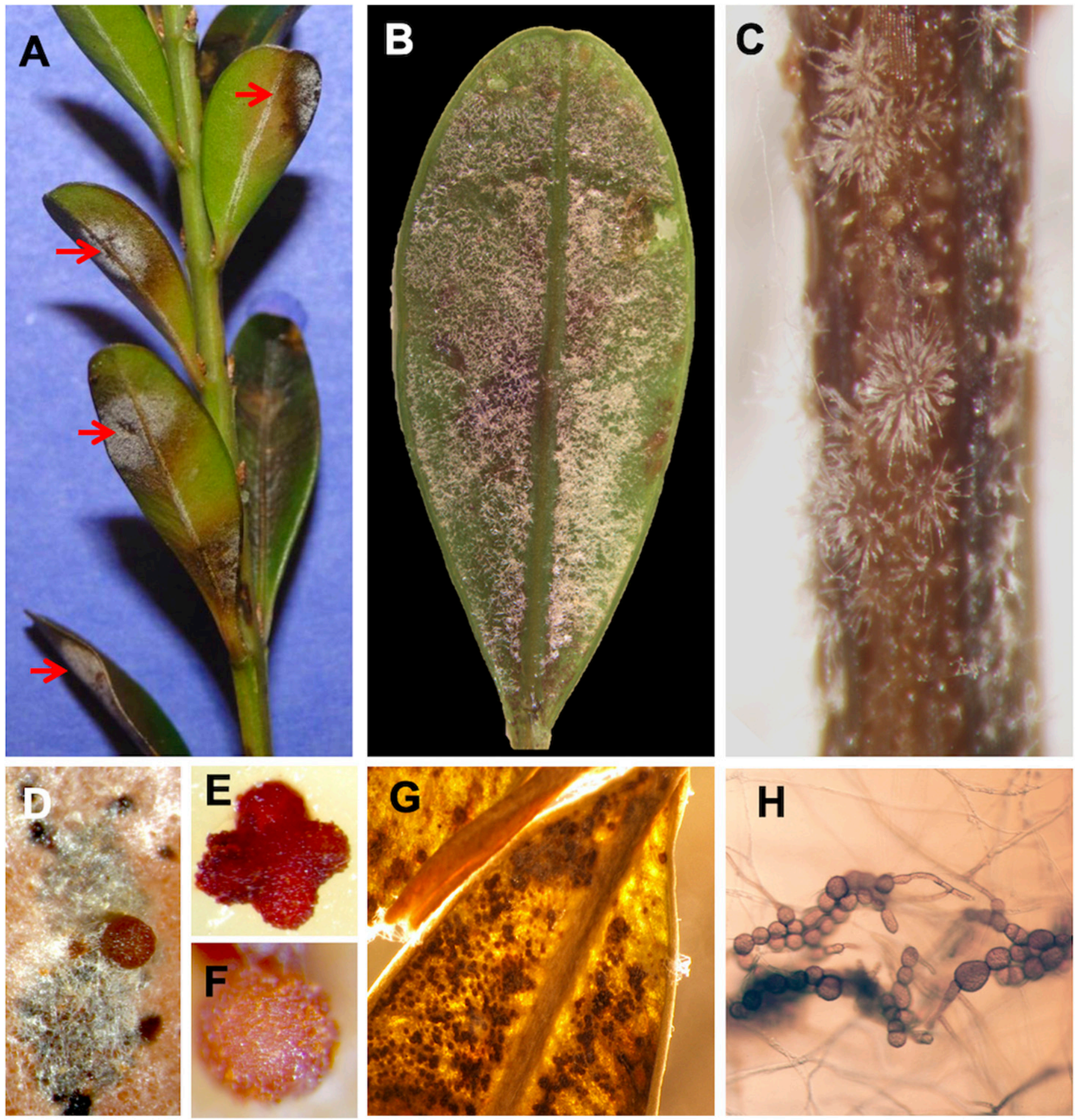

FIGURE 4

Signs of Calonectria henricotiae (Che) and C. pseudonaviculata (Cps) on blighted boxwood (Buxus spp.). A, Sporulation on abaxial surface of symptomatic leaves. B, Close-up of $\mathrm{Cps}$ sporulation on a boxwood leaf. C, Sporodochia on stem lesions. D to F, Perithecia produced by crosses of $C h e$ and $C p s$ on artificial medium (carrot agar) under experimental conditions. Perithecia in the images are barren, lacking ascospores. G, Microsclerotia of Cps on boxwood leaf. $\mathbf{H}$, Microsclerotia of Cps produced on artificial medium (yeast extract agar). Panel A courtesy of the Connecticut Agricultural Experimental Station; panels D to F courtesy of Yazmín Rivera (U.S. Department of Agriculture, Agriculture Research Service, USDA-ARS); panels G and H courtesy of Nina Shishkoff (USDA-ARS). 
(LaMondia 2017). Che is shown to infect $P$. terminalis 'Compacta' under experimental conditions (Bartíková et al. 2020a).

The host range of Cps is also shown to include plant species outside of the Buxaceae family under experimental conditions. Under environmental conditions favorable for disease development (constant high humidity level and $23^{\circ} \mathrm{C}$ ) and using a relatively high inoculum concentration of $1.2 \times 10^{5}$ conidia/ml, Cps caused 3 to $25 \%$ foliar infection on Alchemilla mollis, Arctostaphylos uva-ursi, Brunnera macrophylla, Callirhoe involucrata, Epimedium $\times$ youngianum, Galium odoratum, Iberis sempervirens, Mazus reptans, Phlox subulata, Tiarella cordifolia, and Vinca minor and up to $75 \%$ foliar infection of Geranium sanguineum (Richardson et al. 2020). These non-Buxaceae plants are groundcovers and herbaceous perennials that are often grown as companion plants to boxwood in cultivated landscapes (Richardson et al. 2020). It is unknown whether these plants are natural hosts under more typical environmental conditions. Whether Che can infect the same group of plant species also warrants further investigation.

\section{Geographic Distribution}

Boxwood blight was first documented as a new disease in the United Kingdom in 1994 (Henricot and Culham 2002) when it occurred in a Hampshire nursery. A second report came from New Zealand in 1998 (Ridley 1998). No source was apparent in either case, and it was presumed that the pathogen had been introduced in both instances from an unknown location (Crous 2002; Crous et al. 2002; Gehesquière et al. 2016; Henricot and Culham 2002).

Over the past 25 years, $C p s$ has appeared in many countries where boxwoods are cultivated or inhabit natural ecosystems (Fig. 7). In addition to the United Kingdom and New Zealand, boxwood blight caused by $C p s$ is documented from Abkhazia, Austria, Belgium, Croatia, the Czech Republic, Denmark, France, Georgia, Germany, Iran, Ireland, Italy, the Netherlands, Norway (Skåne province), Russia (Krasnodar Krai), Slovenia, Spain, Sweden (Austlandet and Vestlandet regions), Switzerland, and Turkey (Daughtrey 2019; Rosender 2012; Talgö 2010; Wahlsteen and Lorentzon 2011). Boxwood blight is also reported in North America from Canada and 30 states across the United States (Fig. 7), with thousands of sightings since 2011 (Daughtrey 2019; Elmhirst et al. 2013; Ivors et al. 2012).

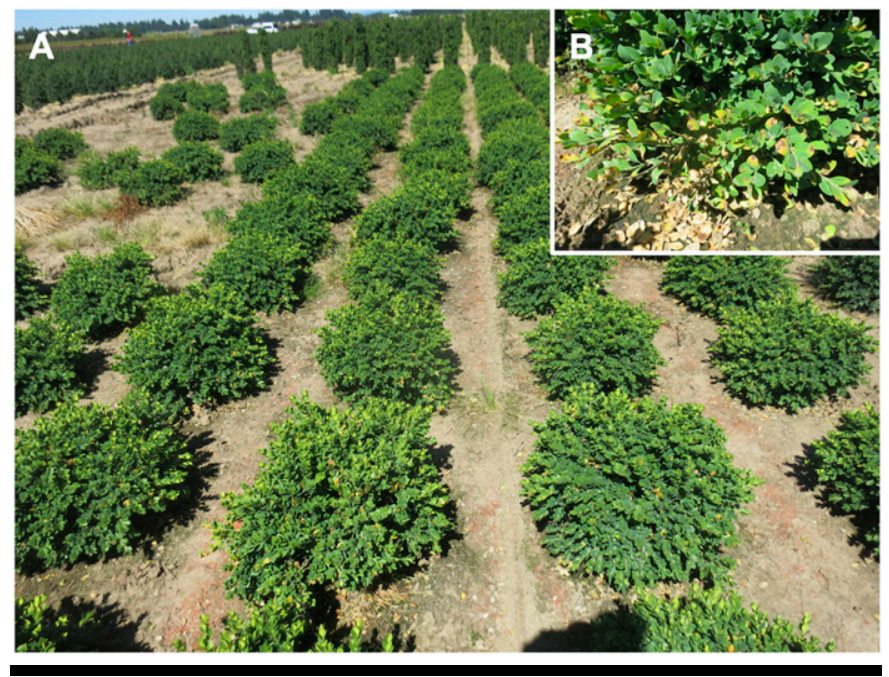

FIGURE 5

A, Misleading healthy appearance of a field production plot with $100 \%$ incidence of boxwood blight on boxwood (cv. 'Vardar Valley') in a nursery in Willamette Valley (Oregon, United States). B, Close-up of disease symptoms.
The latest U.S. sightings of boxwood blight are from Arkansas in 2019 (S. Smith, personal communication; Castroagudín et al. 2020), New Hampshire in 2019 (C. Smith, personal communication), and South Dakota in 2019 (J. Ostrander, personal communication). All detections in Canada and the United States are from ornamental plants: there are no native Buxus or Sarcococca spp. in North America and only one native Pachysandra, namely $P$. procumbens (Daughtrey 2019).

Boxwood blight caused by $C p s$ is also reported from native stands of Buxus in southwestern Asia (Akıllı Şimşek et al. 2019; Gasich et al. 2013; Gorgiladze et al. 2011; Lehtijärvi et al. 2014; Mirabolfathy et al. 2013). Infected forest populations of B. sempervirens are reported from Iran, Turkey, and the United Kingdom (Akıllı Şimşek et al. 2019; Henricot and Culham 2002; Lehtijärvi et al. 2014; Mirabolfathy et al. 2013), and B. colchica has been affected by Cps in Abkhazia and Georgia (Gasich et al. 2013; Gorgiladze et al. 2011).

In contrast to the widespread global distribution of Cps, Che is presently detected only in six European countries: Belgium, the Czech Republic, Germany, the Netherlands, Slovenia, and the United Kingdom (Bartíková et al. 2020a, 2020b; LeBlanc et al. 2019) (Fig. 7).

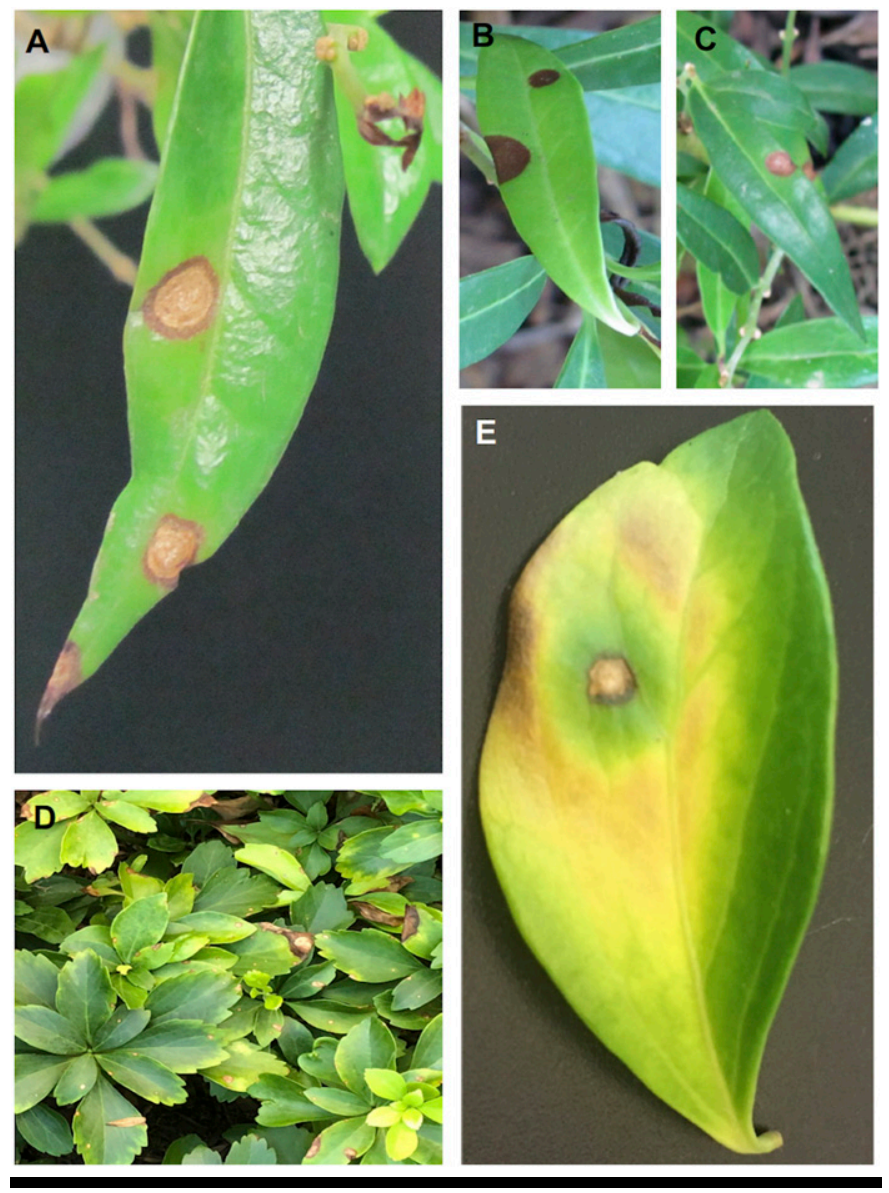

FIGURE 6

Leaf spots caused by Calonectria pseudonaviculata infection of Buxaceae hosts. A to C, Sweetbox (Sarcococca hookeriana). D and E, Japanese pachysandra (Pachysandra terminalis). Panels $A$ to $C$ courtesy of Karen Rane and Dave Clement (University of Maryland); panel D courtesy of Yonghao Li (Connecticut Agricultural Experimental Station); and panel E courtesy of Sandra Vultaggio (Cornell Cooperative Extension of Suffolk County). 


\section{Pathogen Identification}

Laboratory identification of the boxwood blight fungi is best done by directly examining host material rather than by culturing, because the pathogens are slow-growing and do not compete well with other microorganisms. Sporulation may be observed on infected plant parts, especially leaves (Figs. 4A to C). Look for blighted leaves or brown to black leaf spots with diffuse rather than discrete margins, and examine the adaxial surface of these discolored areas with a dissecting microscope for whitish sporulation. If overall symptoms indicate boxwood blight but sporulation is absent, incubate leaves and/or twigs in a moist chamber at room temperature for several days up to 2 weeks to encourage sporulation. If most leaves have abscised, check for sporulation on the black stem lesions (Figs. 3C and 4C).

The asexual spores (conidia) of Che and Cps (Fig. 8A and B) and their appearance in culture (Fig. 8D) will appear familiar to any diagnostician acquainted with other Calonectria spp. (Lombard et al. 2010a, 2010b). Other Calonectria spp., however, have only rarely been reported from boxwood, namely, C. cephalosporii from South Africa and C. lauri and C. pyrochroa from Belgium (Farr and Rossman 2020). Sporulation of Che and Cps on boxwood tissue at low magnification will appear as dense columnar groups of whitish conidiophores, each bearing conidia on penicillate branches as well as a single elongated sterile appendage that ends in a swollen vesicle (Fig. 8A to C). Because sporulation of Pseudonectria buxi and P. foliicola, commonly seen on moribund tissues of boxwood (Rivera et al. 2018; Shi and Hsiang 2014), appears white before it acquires its characteristic pink pigmentation, Pseudonectria can easily be mistaken for the boxwood blight fungi without examination at higher magnification. Fusarium buxicola with white sporulation is also commonly encountered on boxwood leaves and stems (Farr and Rossman 2020). A practiced eye can usually distinguish Che/
Cps conidiophores amid sporulation of other fungal genera, recognizing them by the columnar, almost crystalline form of the tightly clustered, vertically oriented macroconidia and the sterile appendages that seem to tower above them.

For accurate morphological identification, however, a sample of sporulation suspected to be Che/Cps should be transferred to a droplet of water on a glass slide and examined with a compound microscope, in order to observe the distinctive conidia and conidiophores (Fig. 8). Che and $C p s$ conidia are cylindrical and relatively large, from 42.0 to 66.5 (to 80 ) $\mu \mathrm{m}$ in length and 3.8 to 7.5 (to 7.9 ) $\mu \mathrm{m}$ wide, with parallel sides, rounded ends, and usually a single septation, traits that distinguish them from other fungi seen on boxwood. The macroconidia of these two species are borne on a penicillately branched stipe, 50 to $155 \mu \mathrm{m}$ long, on branches having doliiform to reniform phialides (Crous et al. 2002; Gehesquière et al. 2016; Henricot and Culham 2002). The vesicles at the end of the stipe extensions have pointed or papillate apices, thus appearing naviculate (boat-shaped) (Crous et al. 2002; Gehesquière et al. 2016; Henricot and Culham 2002). Che and Cps do not present any significant morphological differences that would allow for differentiation through visual examination (Gehesquière et al. 2016), although Che stipe extensions and phialides on average are shorter than those of $C p s$, whereas the macroconidia of $C h e$ are wider on average than those of $C p s$ (Crous et al. 2002; Gehesquière et al. 2016; Henricot and Culham 2002). To discriminate between $C h e$ and $C p s$, molecular diagnostic methods are required (Gehesquière et al. 2016) (see the Molecular Methods for Pathogen Detection section below).

\section{Pathogen Isolation}

Boxwood blight pathogens can be isolated by placing infected leaves and stems into a moist chamber and incubating at 20 to $25^{\circ} \mathrm{C}$ in either the dark or under a 12-h light cycle. Spores develop within

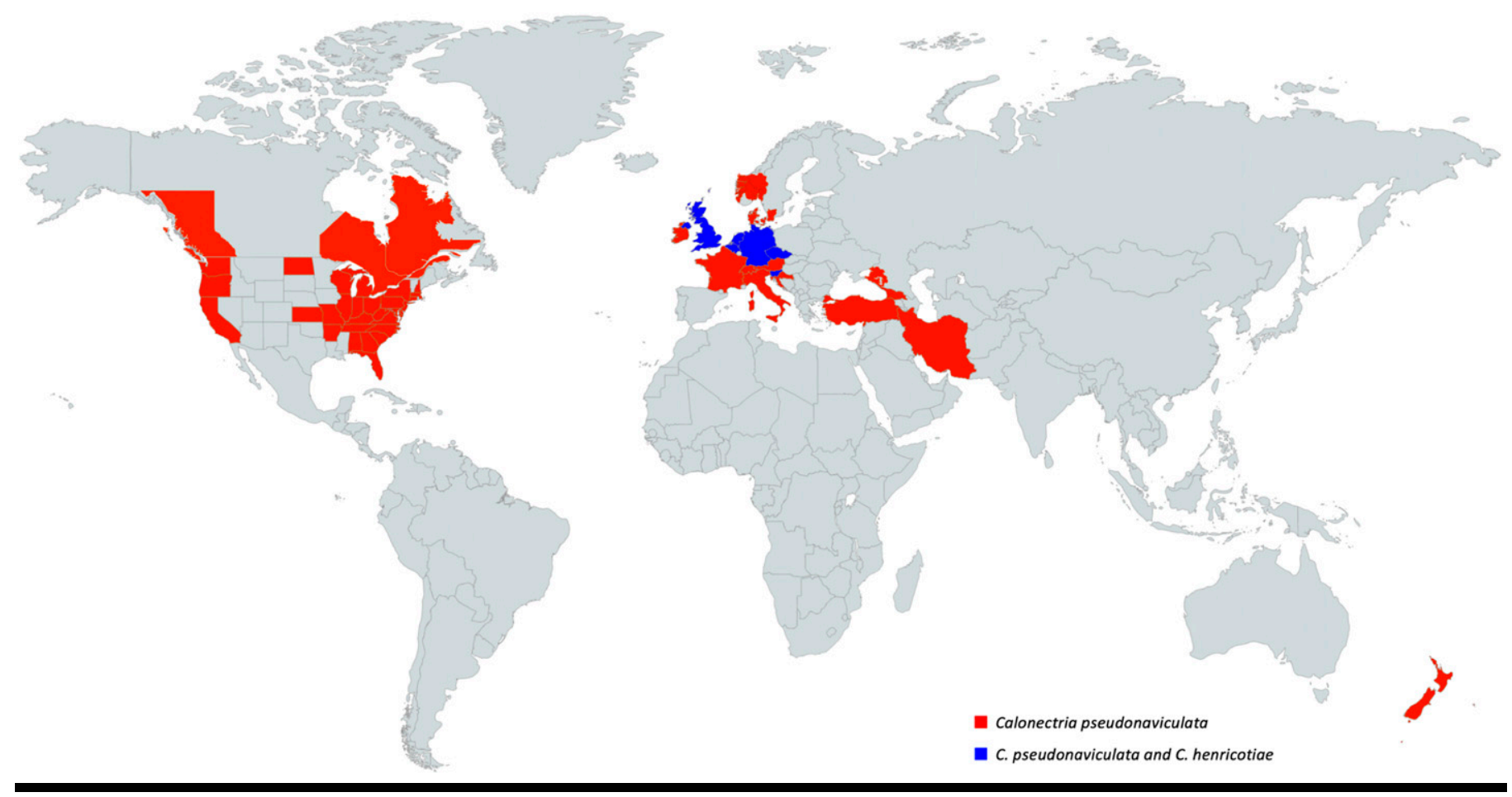

FIGURE 7

Worldwide distribution of Calonectria pseudonaviculata (Cps) in red; in blue are countries where both Cps and C. henricotiae are reported. Reports include observations on ornamentals in production, wholesale and retail nurseries and garden centers, established landscapes, and natural ecosystems. 
2 to 7 days, but samples should be checked daily because other microorganisms may quickly overgrow and contaminate the slower growing Che and Cps colonies. Once spores are observed, a sterile loop, dipped into sterile water, may be used to pick up spores and then streak them onto full- or half-strength potato dextrose agar (PDA) medium amended with streptomycin $(50 \mathrm{mg} / \mathrm{liter})$ or streptomycin and neomycin ( $30 \mathrm{mg} /$ liter, each) to inhibit bacteria. A sterile needle may then be used to transfer a small agar square containing a single conidium. Spores germinate within a few days, and single-spore isolates may also be obtained by transferring germinated spores to new plates. When collecting spores from leaves, care must be taken to avoid areas containing salmon-colored sporodochia of Pseudonectria buxi and P. foliicola (Rivera et al. 2018), which are other common boxwood pathogens, because Pseudonectria rapidly outcompete Che and Cps in culture. Calonectria and Pseudonectria often co-occur on the same tissues; however, the rod-like spores of Che and Cps are easily distinguishable from the shorter, elliptical spores of Pseudonectria at $400 \times$. Cultures of Calonectria are slow growing with a tan to brown center and white edges, whereas the faster growing Pseudonectria develops a salmon pink center with a white edge.

Infected tissues may also be placed onto PDA amended with antibiotics. First, surface sterilize tissues by immersing in $70 \%$ ethanol for $1 \mathrm{~min}$, followed by $1 \% \mathrm{NaOCl}$ for $1 \mathrm{~min}$ followed by two rinses in sterile deionized water before allowing to dry for $1 \mathrm{~min}$ in a laminar flow hood. Use a sterile scalpel blade or needle to cut smaller subsamples (up to $5 \mathrm{~mm}^{2}$ ) and transfer onto PDA medium.
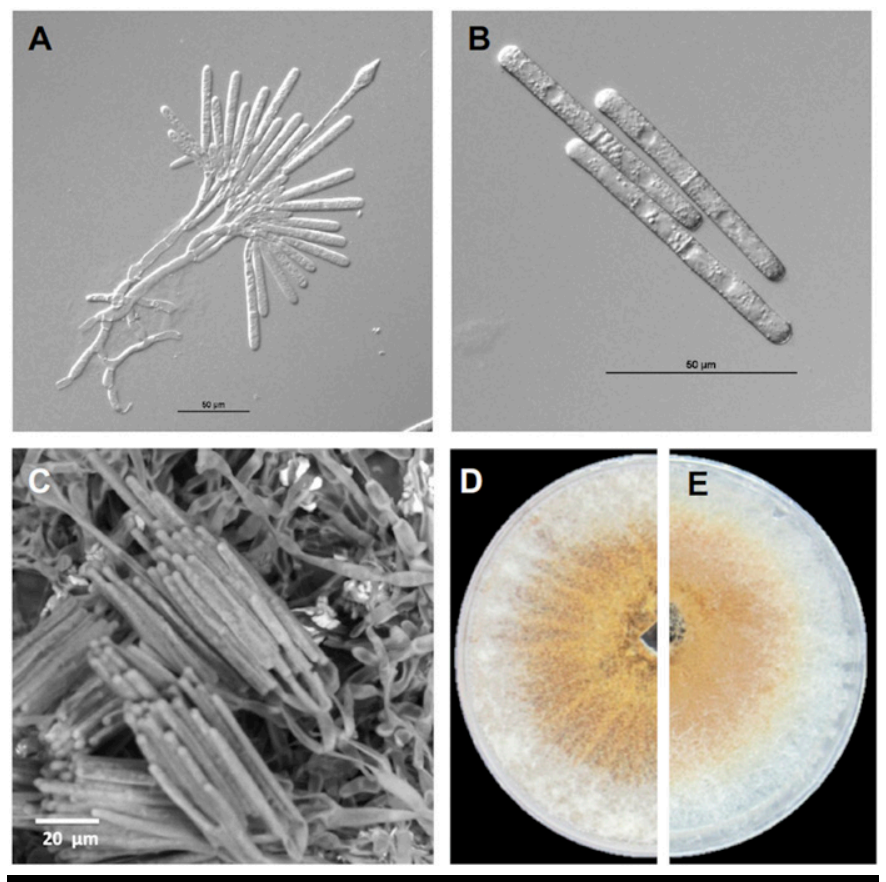

\section{FIGURE 8}

A, Conidiogenous apparatus of Calonectria pseudonaviculata (Cps), showing stipe with penicillate branches bearing cylindrical conidia, as well as a stipe extension with a naviculate apex. B, Cylindrical conidia of $C p s$, with parallel sides, rounded ends, and a single septum. C, Scanning electron microscopic images of the conidiogenous apparatus of $C$. henricotiae (Che) from the abaxial leaf surface. $\mathbf{D}$ and $\mathbf{E}$, Colonies of Che (D) and $C p s(E)$ on potato dextrose agar. Panels $A$ and $B$ courtesy of Bjorn Gehesquière (Flanders Research Institute for Agriculture, Fisheries and Food, ILVO); panels C to E courtesy of Martha Malapi-Wight (U.S. Department of Agriculture, Agriculture Research Service).
Incubate plates as indicated above, and check daily for growth of the pathogen.

\section{Molecular Methods for Pathogen Detection}

Several molecular diagnostic methods provide early detection and accurate diagnosis of the boxwood blight pathogens from asymptomatic and symptomatic tissues. All of the molecular diagnostic tools available for detection and discrimination of Che and Cps rely on either polymerase chain reaction (PCR) or isothermal amplification of target DNA (LeBlanc et al. 2018). A real-time PCR (RT-PCR) assay using a TaqMan probe targeting the rDNA internal transcribed spacer (ITS) region is available and has been tested on plant, water, and soil samples (Gehesquière et al. 2013). The ITS RT-PCR assay is highly sensitive and capable of detecting as little as $10 \mathrm{fg}$ of pathogen DNA of both Che and Cps. Although the ITS RT-PCR assay does not detect distantly related Calonectria (C. colhounii, C. parasiticum, C. pauciramosum, C. scoparium), the assay does detect two very closely related Calonectria spp. (C. naviculata and C. multiphialidica). In theory, detection of these two closely related Calonectria spp. could result in false positives, but from a practical standpoint there are no reports of $C$. naviculata and $C$. multiphialidica infecting boxwood (Gehesquière et al. 2013). A SYBRgreen-based RT-PCR assay targeting beta-tubulin ( $\beta$-Tub) DNA and fully specific for Cps is also available (Gehesquière et al. 2013). Although the $\beta$-Tub RT-PCR assay has a lower level of sensitivity than the rDNA ITS RT-PCR assay, it is fully specific for Cps and is still able to detect the pathogen in $20 \mathrm{~g}$ of plant material with only $1 \mathrm{ppm}$ of the infected tissue, in 10-ml water samples containing as little as 1 conidium/ $\mathrm{ml}$, and in tape pieces from spore traps containing as few as 10 conidia (Gehesquière et al. 2013). Additional RT-PCR assays with locked nucleic acid (LNA)-based probes are also available, targeting DNA at the histone 3 (H3), $\beta$-Tub, and calmodulin loci (Gehesquière et al. 2016). These three RT-PCR-LNA assays detect and discriminate between Che and $C p s$ with high specificity and sensitivity, with a limit of detection of 100 pg (Gehesquière et al. 2016). Modified versions of the ITS and H3 RT-PCR assays are also available; these assays rely on conventional PCR or SYBR-green RT-PCR, and they provide species-specific detection of Che and Cps at levels as low as $\sim 1 \mathrm{pg}$ (Guo and Pooler 2020).

Two loop-mediated isothermal amplification (LAMP) assays are also available for differential detection of Che and Cps (Malapi-Wight et al. 2016a). These assays are highly specific and have a detection limit of $100 \mathrm{pg}$ of pathogen DNA. Because the LAMP assays are based on isothermal DNA amplification, they do not require the use of thermal cyclers. Whole-genome sequences have also been used to confirm the identity of Cps isolates (Malapi-Wight et al. 2016b), and several genome sequences are publicly available for both $C h e$ and $C p s$ for comparative use (Crouch et al. 2017; LeBlanc et al. 2019).

At present, none of the available molecular diagnostic assays have been fully developed for use in the field, and most of the available assays require relatively expensive equipment and highly trained users. Antibody and DNA-based approaches that rely on lateral flow dipstick devices for point-of-use testing are currently in development to provide rapid, field-deployable detection of both Che and Cps (D. G. Luster, personal communication).

\section{Pathogen Storage}

Multiple methods are available for maintaining cultures of Che and Cps for different periods of time. For short-term storage ( $<6$ months) or frequent use, isolates of Che and Cps can be maintained through continuous growth on PDA, V8 vegetable juice agar, malt extract agar, carnation leaf agar, or glycerol, yeast extract, and tyrosine agar (GYET) media (Crous 2002; MalapiWight et al. 2014). Colonies can be grown on agar media in 
Parafilm-sealed Petri plates or agar slants in glass culture tubes with screw caps, incubated at 20 to $25^{\circ} \mathrm{C}$ with a 12 -h photoperiod (natural light or any source of fluorescent light is adequate for vegetative growth; to induce sporulation, see the Pathogenicity Tests section, below), and regularly subcultured every 3 to 4 weeks (Gehesquière et al. 2016). Subculturing might cause changes in morphology or a decrease in virulence that could affect experimental results; therefore, it is recommended not to exceed four subculturing cycles (Crous 2002).

For medium-term storage, 1-week-old cultures growing on PDA agar slants in glass tubes can be incubated at 4 to $8^{\circ} \mathrm{C}$ and preserved up to 2 years (Nishi and Takahashi 1990). Subculturing to a new tube with fresh medium should occur every 12 to 18 months to ensure isolate purity and viability (Nakasone et al. 2004).

Mycelial plugs of actively growing cultures can be preserved for 1 to 10 years in sterile glycerol ( $30 \% \mathrm{v} / \mathrm{v}$ in deionized water). Cut eight to 10 mycelial plugs $(<6 \mathrm{~mm})$ with a sterilized disposable pipette tip or cork borer from the edge of an actively growing fungal colony using sterile technique. Transfer plugs to a $1.8-\mathrm{ml}$ sterile screw-cap cryogenic tube that is filled with $700 \mu \mathrm{l}$ of sterile glycerol solution. The tube is loosely capped and incubated at $4^{\circ} \mathrm{C}$ for $24 \mathrm{~h}$, and then the cap is hand tightened and the tube is maintained at $4^{\circ} \mathrm{C}$ for medium-term storage ( $>1$ year) or transferred to -20 or $-80^{\circ} \mathrm{C}$ for long-term storage (up to 10 years) (Nakasone et al. 2004). When reviving, frozen tubes should be thawed gradually in an ice or water bath until reaching room temperature before removing a mycelial plug aseptically (Nakasone et al. 2004).

Conidium, chlamydospore, and microsclerotium suspensions can be prepared as described below in the Pathogenicity Tests section (Ryan et al. 2018; Shishkoff and Camp 2016). Concentrate the suspensions of these propagules by centrifugation; discard the supernatant and resuspend the propagules in $1 \mathrm{ml}$ of sterile glycerol solution $(10 \% \mathrm{v} / \mathrm{v}$ in deionized water). Transfer aliquots of $700 \mu \mathrm{l}$ to $1 \mathrm{ml}$ to sterilized cryogenic tubes and preserve them at -20 or $-80^{\circ} \mathrm{C}$ for long-term storage (Risède and Rhino 2008). Che and Cps microsclerotia remained viable for more than 2 years when preserved as microsclerotia-colonized cellophane squares kept over sterile, moist sand at $10^{\circ} \mathrm{C}$ (Shishkoff and Camp 2016). In addition, microsclerotia-colonized cellophane disks grown in GYET medium can be stored at room temperature $\left(20\right.$ to $\left.25^{\circ} \mathrm{C}\right)$ for up to 1 year, or at $10^{\circ} \mathrm{C}$ for up to 5 years (N. Shishkoff, personal communication). In all cases, growth should be observed within 3 to 5 days after reviving isolates from storage.

\section{Pathogenicity Tests}

Spraying a conidial suspension onto whole plants is recommended to test pathogenicity of Che and Cps isolates (LaMondia and Shishkoff 2017). Other methods have been used for pathogenicity tests, including placing mycelial plugs or conidial suspensions onto wounded tissues (Crepel and Inghelbrecht 2003; Guo et al. 2015) or dipping detached stems and leaves into spore suspensions (Henricot et al. 2008; Shishkoff et al. 2015). These other methods are useful for quick assessments of host susceptibility but may not be directly comparable to results obtained from living host tissue that remains attached to the entire plant (Guo et al. 2015; Shishkoff et al. 2015).

Conidia are produced in one of two recommended ways: (i) Grow Che or Cps mycelia in potato dextrose broth $(75$ to $100 \mathrm{ml}$ of medium in a $250-\mathrm{ml}$ Erlenmeyer flask or 10 to $15 \mathrm{ml}$ of medium in a 10 -cm Petri dish) at $23^{\circ} \mathrm{C}$ for 4 days with continuous shaking at 100 rpm (if Petri plates are used, do not shake), rinse the mycelial mat with sterile deionized water, and follow with a 3-day fluorescent light exposure (Kong et al. 2017a). (ii) Produce Che or Cps microsclerotia on cellophane sheets covering the surface of GYET (Hunter 1992) at $20^{\circ} \mathrm{C}$ for 1 to 2 months, and then place the colonized sheets onto fresh GYET to let microsclerotia produce conidia (Shishkoff et al. 2015). If the two recommended methods fail to produce conidia, other methods include growing cultures on carnation leaf agar (Henricot et al. 2008), V8 agar (Malapi-Wight et al. 2014), half-strength PDA (LaMondia 2015), PDA (Ryan et al. 2018), or using the "flood inoculation" method described by Miller et al. (2018). Scraping cultures under sterile conditions to remove aerial mycelium and then placing the cultures under a 12-h light (200 $\mu \mathrm{E} \mathrm{m}^{-2} \mathrm{~s}^{-1}$; fluorescent light)/12-h dark cycle have also been shown to encourage sporulation (LaMondia 2015; Ryan et al. 2018). The flood inoculation method was successfully used to produce abundant conidia with Che (Bartíková et al. 2020a); however, depending on the isolate, special methods may be needed (Miller et al. 2018).

Concentrations of conidia for Che and Cps pathogenicity tests can range from $10^{4}$ to $10^{6}$ conidia/ml, which might be thought of as correlating with a plant's exposure to inoculum during adverse to favorable environmental conditions for disease development, or to inoculum produced on resistant to susceptible host plants, respectively (LaMondia 2017; LaMondia et al. 2012; MalapiWight et al. 2014). Suspend conidia in sterile water and adjust the concentration, using a hemocytometer, by adding more water. Although the volume per plant will differ based on plant size, a typical volume is $20 \mathrm{ml}$ to spray a $15-\mathrm{cm}$-tall plant to run-off. If clumps of conidia are observed under the microscope, add Tween 20 (Bio-Rad Laboratories, Richmond, CA) to the suspension (0.01 to $0.1 \% \mathrm{v} / \mathrm{v})$. Spray freshly prepared conidial suspensions evenly onto plant foliage using a plastic trigger hand sprayer of any brand. A pressure sprayer can also be used when a large inoculum volume needs to be sprayed (Yang and Hong 2018).

Place inoculated plants in a dew chamber (Blomquist et al. 2018; LaMondia and Shishkoff 2017), covered humid container (Kong et al. 2017a; Richardson et al. 2020), or mist tent at near $100 \%$ relative humidity, $23^{\circ} \mathrm{C}$ for 24 to $72 \mathrm{~h}$, with a natural light regime. Then transfer inoculated plants to a laboratory or greenhouse at 18 to $25^{\circ} \mathrm{C}$ and irrigate as needed. Assess disease incidence and/or severity 5 to 15 days after inoculation, depending on disease progression (LaMondia and Shishkoff 2017; Shishkoff et al. 2015).

\section{Literature Cited}

Akıllı Şimşek, S., Katırcıŏ̆lu, Y. Z., Çakar, D., Rigling, D., and Maden, S. 2019. Impact of fungal diseases on common box (Buxus sempervirens L.) vegetation in Turkey. Eur. J. Plant Pathol. 153:1203-1220.

Bartíková, M., Brand, T., Beltz, H., and Šafránková, I. 2020a. Host susceptibility and microclimatic conditions influencing the development of blight diseases caused by Calonectria henricotiae. Eur. J. Plant Pathol. 157: 103-117.

Bartíková, M., Holková, L., and Šafránková, I. 2020b. Occurrence of boxwood blight (Calonectria pseudonaviculata and C. henricotiae) in historical gardens in the Czech Republic. Eur. J. Plant Pathol. doi.org/10.1007/s10658020-02061-2

Blomquist, C. L., Kosta, K. L., Santos, P. F., and Rooney-Latham, S. 2018. First report of boxwood blight caused by Calonectria pseudonaviculata in California. Plant Dis. 102:2379.

Castroagudín, V. L., Weiland, J. E., Baysal-Gurel, F., Cubeta, M. A., Daughtrey, M., Ward Gauthier, N., LaMondia, J., Luster, D. G., Peduto Hand, F., Shishkoff, N., Williams-Woodward, J., Yang, X., LeBlanc, N., and Crouch, J. A. 2020. One clonal lineage of Calonectria pseudonaviculata is primarily responsible for the boxwood blight epidemic in the United States. Phytopathology. doi.org/10.1094/PHYTO-04-20-0130-R

Crepel, C., and Inghelbrecht, S. 2003. First report of blight on Buxus spp. caused by Cylindrocladium buxicola in Belgium. Plant Dis. 87:1539. 
Crouch, J. A., Malapi-Wight, M., Rivera, Y., Salgado-Salazar, C., and Veltri, D. 2017. Genome datasets for Calonectria henricotiae and C. pseudonaviculata causing boxwood blight disease and related species. Ag Data Commons. https:// doi.org/10.15482/USDA.ADC/1410184.

Crous, P. W. 2002. Taxonomy and Pathology of Cylindrocladium (Calonectria) and Allied Genera. APS Press, St. Paul, MN.

Crous, P. W., Groenewald, J. Z., and Hill, C. F. 2002. Cylindrocladium pseudonaviculatum sp. nov. from New Zealand, and new Cylindrocladium records from Vietnam. Sydowia 54:23-33.

Daughtrey, M. L. 2019. Boxwood blight: Threat to ornamentals. Annu. Rev. Phytopathol. 57:189-209.

Daughtrey, M. L., Gilrein, D., and Vescera, M. 2016. Photographic guide of boxwood pest and diseases in Long Island. Cornell Cooperative Extension of Suffolk County, Cornell University, Riverhead, NY. http://ccesuffolk.org/ resources/photographic-guide-of-boxwood-pests-diseases-on-long-island. Accessed July 6, 2020.

Douglas, S. M. 2012. Boxwood blight confirmed on Pachysandra in a Connecticut landscape. Connecticut Agricultural Experiment Station, New Haven, CT. https://portal.ct.gov/-/media/CAES/DOCUMENTS/Publications/ Fact_Sheets/Plant_Pathology_and_Ecology/NATURALINFECTIONOFPA CHYSANDRAWITHBOXWOODBLIGHTINCONNECTICUTLANDSC APES070312pdf.pdf?la=en. Accessed April 30, 2020.

Elmhirst, J. F., Auxier, B. E., and Wegener, L. A. 2013. First report of box blight caused by Cylindrocladium pseudonaviculatum (C. buxicola) in British Columbia, Canada. Plant Dis. 97:559.

Farr, D. F., and Rossman, A. Y. 2020. Fungal Databases, U.S. National Fungus Collections, ARS, USDA. https://nt.ars-grin.gov/fungaldatabases/. Accessed April 30, 2020.

Gasich, E. L., Kazartsev, I. A., Gannibal, P. B., Koval, A. G., Shipilova, N. P., Khlopunova, L. B., and Ovsyannikova, E. I. 2013. Calonectria pseudonaviculata-A new for Abkhazia species, the causal agent of boxwood blight. Mikol. Fitopatol. 47:129-131.

Gehesquière, B., Crouch, J. A., Marra, R. E., Van Poucke, K., Rys, F., Maes, M., Gobin, B., Höfte, M., and Heungens, K. 2016. Characterization and taxonomic reassessment of the box blight pathogen Calonectria pseudonaviculata, introducing Calonectria henricotiae sp. nov. Plant Pathol. 65: $37-52$.

Gehesquière, B., D’Haeyer, S., Pham, K. T. K., Van Kuik, A. J., Maes, M., Höfte, M., and Heungens, K. 2013. qPCR assays for the detection of Cylindrocladium buxicola in plant, water, and air samples. Plant Dis. 97:1082-1090.

Gorgiladze, L., Meparishvili, G., Sikharulidze, Z., Natsarishvili, K., and Davitadze, R. 2011. First report of box blight caused by Cylindrocladium buxicola in Georgia. New Dis. Rep. 23:24.

Guo, Y., Olsen, R. T., Kramer, M., and Pooler, M. 2015. Effective bioassays for evaluating boxwood blight susceptibility using detached stem inoculations. HortScience 50:268-271.

Guo, H., and Pooler, M. R. 2020. Real-time and conventional PCR tools for detection and discrimination of Calonectria pseudonaviculata and C. henricotiae causing boxwood blight. Plant Dis. https://doi.org/10.1094/PDIS-0919-2053-RE.

Henricot, B., and Culham, A. 2002. Cylindrocladium buxicola, a new species affecting Buxus spp., and its phylogenetic status. Mycologia 94: 980-997.

Henricot, B., Gorton, C., Denton, G., and Denton, J. 2008. Studies on the control of Cylindrocladium buxicola using fungicides and host resistance. Plant Dis. 92:1273-1279.

Henricot, B., Pérez Sierra, A., and Prior, C. 2000. A new blight disease on Buxus in the UK caused by the fungus Cylindrocladium. Plant Pathol. 49:805.

Hunter, B. B. 1992. Cylindrocladium. Pages 107-110 and 248 in: Methods for Research on Soilborne Phytopathogenic Fungi. L. L. Singleton, J. D. Mihail, and C. M. Rush, eds. APS Press, St. Paul, MN.

Ivors, K. L., Lacey, L. W., Milks, D. C., Douglas, S. M., Inman, M. K., Marra, R. E., and LaMondia, J. A. 2012. First report of boxwood blight caused by Cylindrocladium pseudonaviculatum in the United States. Plant Dis. 96:1070.

Kong, P., Likins, T. M., and Hong, C. X. 2017a. First report of blight of Sarcococca hookeriana var. humilis by Calonectria pseudonaviculata in Virginia. Plant Dis. 101:247.

Kong, P., Likins, T. M., and Hong, C. X. 2017b. First report of Pachysandra terminalis leaf spot by Calonectria pseudonaviculata in Virginia. Plant Dis. 101:509.

Kramer, M., Guo, Y., and Pooler, M. 2020. Ranking resistance of Buxus cultivars to boxwood blight-An integrated analysis. J. Environ. Hortic. 38:50-55.

LaMondia, J. A. 2015. Management of Calonectria pseudonaviculata in boxwood with fungicides and less susceptible host species and varieties. Plant Dis. 99:363-369.
LaMondia, J. A. 2017. Pachysandra species and cultivar susceptibility to the boxwood blight pathogen, Calonectria pseudonaviculata. Plant Health Prog. 18:41-43.

LaMondia, J. A., and Li, D. W. 2013. Calonectria pseudonaviculata can cause leaf spot and stem blight of Pachysandra procumbens. Plant Health Prog. 14. doi: 10.1094/PHP-2013-0226-01-BR.

LaMondia, J. A., Li, D. W., Marra, R. E., and Douglas, S. M. 2012. First report of Cylindrocladium pseudonaviculatum causing leaf spots on Pachysandra terminalis. Plant Dis. 96:1069.

LaMondia, J. A., and Shishkoff, N. 2017. Susceptibility of boxwood accessions from the National Boxwood Collection to boxwood blight and potential for differences between Calonectria pseudonaviculata and $C$. henricotiae. HortScience 52:873-879.

LeBlanc, N., Gehesquière, B., Salgado-Salazar, C., Heungens, K., and Crouch, J. A. 2019. Limited genetic diversity across pathogen populations responsible for the global emergence of boxwood blight identified using SSRs. Plant Pathol. 68:861-868.

LeBlanc, N. L., Salgado-Salazar, C., and Crouch, J. A. 2018. Boxwood blight: An ongoing threat to ornamental and native boxwood. Appl. Microbiol. Biotechnol. 102:4371-4380.

Lehtijärvi, A., Dogmus-Lehtijärvi, H. T., and Oskay, F. 2014. Boxwood blight in Turkey: Impact on natural boxwood populations and management challenges. Balt. For. 23:274-278.

Lombard, L., Crous, P. W., Wingfield, B. D., and Wingfield, M. J. 2010a. Phylogeny and systematics of the genus Calonectria. Stud. Mycol. 66: 31-69.

Lombard, L., Crous, P. W., Wingfield, B. D., and Wingfield, M. J. 2010 b. Species concepts in Calonectria (Cylindrocladium). Stud. Mycol. 66: $1-13$.

Malapi-Wight, M., Demers, J., Veltri, D., Marra, R. E., and Crouch, J. A. 2016a. LAMP detection assays for boxwood blight pathogens: A comparative genomics approach. Sci. Rep. 6:26140.

Malapi-Wight, M., Hébert, J. B., Buckley, R., Daughtrey, M. L., Gregory, N. F., Rane, K., Tirpak, S., and Crouch, J. A. 2014. First report of boxwood blight caused by Calonectria pseudonaviculata in Delaware, Maryland, New Jersey, and New York. Plant Dis. 98:698.

Malapi-Wight, M., Salgado-Salazar, C., Demers, J. E., Clement, D. L., Rane, K. K., and Crouch, J. A. 2016b. Sarcococca blight: Use of wholegenome sequencing for fungal plant disease diagnosis. Plant Dis. 100: 1093-1100.

Miller, M. E., Shishkoff, N., and Cubeta, M. A. 2018. Thermal sensitivity of Calonectria henricotiae and Calonectria pseudonaviculata conidia and microsclerotia. Mycologia 110:546-558.

Mirabolfathy, M., Ahangaran, Y., Lombard, L., and Crous, P. W. 2013. Leaf blight of Buxus sempervirens in northern forests of Iran caused by Calonectria pseudonaviculata. Plant Dis. 97:1121-1122.

Nakasone, K. K., Peterson, S. W., and Jong, S.-C. 2004. Preservation and distribution of fungal cultures. Pages 34-47 in: Biodiversity of Fungi: Inventory and Monitoring Methods. G. Bills, G. M. Muller, and M. S. Foster, eds. Elsevier, Amsterdam, The Netherlands.

Nishi, K., and Takahashi, H. 1990. Influence of low temperature preservation on survival of Calonectria crotalariae. Proc. Kanto-Tosan Plant Prot. Soc. 37: 51-53.

Richardson, P. A., Daughtrey, M., and Hong, C. X. 2020. Indications of susceptibility to Calonectria pseudonaviculata in some common groundcovers and boxwood companion plants. Plant Dis. 104:1127-1132.

Ridley, G. 1998. New plant fungus found in Auckland box hedges (Buxus). For. Health News 77:1-2.

Risède, J.-M., and Rhino, B. 2008. Long-term maintenance of Cylindrocladium strains and procedures for inoculum production. Fruits 63:193-197.

Rivera, Y., Salgado-Salazar, C., Veltri, D., Malapi-Wight, M., and Crouch, J. A. 2018. Genome analysis of the ubiquitous boxwood pathogen Pseudonectria foliicola. PeerJ 6:e5401.

Rosender, C. 2012. Box blight—Distribution and spread rate in the churchyards of Malmö. Department of Landscaping Architecture, Swedish University of Agricultural Sciences, Alnarp, Sweden.

Ryan, C., Williams-Woodward, J., and Zhang, D. L. 2018. Susceptibility of Sarcococca taxa to boxwood blight by Calonectria pseudonaviculata. Pages 64-67 in: Proceedings of Southern Nursery Association Research Conference, Vol. 62. Southern Nursery Association, Acworth, GA.

Sacher, G. O., Weiland, J. E., Putnam, M. L., Crouch, J. A., and Castroagudín, V. L. 2020. Confirmation of Calonectria pseudonaviculata causing boxwood blight of Buxus cultivars in Oregon. Plant Dis. 104:1862. 
Shi, F., and Hsiang, T. 2014. Pseudonectria buxi causing leaf and stem blight on Buxus in Canada. Eur. J. Plant Pathol. 138:763-773.

Shishkoff, N., and Camp, M. 2016. The effect of different temperatures and moisture levels on survival of Calonectria pseudonaviculata in boxwood leaves and twigs and as microsclerotia produced in culture. Plant Dis. 100: 2018-2024.

Shishkoff, N., Daughtrey, M., Aker, S., and Olsen, R. T. 2015. Evaluating boxwood susceptibility to Calonectria pseudonaviculata using cuttings from the National Boxwood Collection. Plant Health Prog. 16:11-15.

Singh, R., and Doyle, V. P. 2017. Boxwood dieback caused by Colletotrichum theobromicola: A diagnostic guide. Plant Health Prog. 18:174-180.
Talgö, V. 2010. New fungal disease destroys boxwood hedges. Bioforsk Theme 5:1-4.

Wahlsteen, E., and Lorentzon, K. 2011. Boxwood blight-A serious threat to beloved garden plants. https://naturochtradgard.se/2011/12/01/buxbomssot $\% \mathrm{E} 2 \% 80 \%$ A8-allvarligt-hot-mot-alskad-tradgardsvaxt/. Accessed April 30, 2020.

Weiland, J. E., and Pscheidt, J. W. 2020. Scouting for boxwood blight. Digger Mag. March 2020:25-28. http://www.diggermagazine.com/scouting-forboxwood-blight/.

Yang, X., and Hong, C. 2018. Biological control of boxwood blight by Pseudomonas protegens recovered from recycling irrigation systems. Biol. Control 124:68-73. 